\title{
Voluntary disclosure of listed banks operating in Ghana
}

\author{
Philemon Adjei Koduah \\ University of Education, Winneba - Kumasi Campus
}

\begin{abstract}
Issues of voluntary disclosure have become relevant in Ghana after the Bank of Ghana took steps to rationalised banks in Ghana to strengthen the banking sector. The sudden collapse of some banks in Ghana may have raised some doubts among investors and other stakeholders with regards to the quality of information disclosed by banks in Ghana. It has therefore become important for banks in Ghana to improve the quality of financial information by setting up good governance structures and to provide adequate voluntary information in their annual reports to boost the confidence of investors and other stakeholders. This study examines the extent to which listed banks in Ghana voluntarily disclose information in their annual report for the 2018 period and to determine the differences in the types of information voluntarily disclosed by listed banks in Ghana. This study revealed an overall voluntary disclosure level mean of 0.6294 which was slightly above average. The Tukey post hoc test showed a statistical significant difference between strategic information and non-financial information as well as a statistical significant difference between strategic information and financial information. However, there is no statistical significant difference between non-financial information and financial information. The study concludes that adequate voluntary information must be provided in the annual reports of listed banks in Ghana to ensure transparency, consistency, reliability and comparability to influence the economic decision needs of investors and other users of accounting information.
\end{abstract}

Keywords: voluntary disclosure, strategic information, non-financial information, financial information, listed banks in Ghana.

\section{Introduction}

Companies desire to raise capital from investors in the capital market necessitates the provision of voluntary accounting information (Choi, 1973). This motivate companies to willingly provide excess non statutory information in their annual report to be useful to several stakeholders (such as owners of the business, potential shareholders, bankers, people in academia, financial advisors, the general public etc.) in making economic and investment decision.

Voluntary disclosure involves providing excess of private accounting and 
supplementary information subject to audit and other regulatory scrutiny, intended to be used by management but considered to be pertinent to the economic decision exigency of users of accounting details. Providing adequate voluntary details assist users to have a fair view of what goes on in a company and also benefit companies and the general economy of a country as well as lowering companies cost of capital (Leuz \& Verrecchia, 2000; Choi \& Levich, 1990; Diamond \& Verrecchia, 1991; Healy \& Palepu, 2001; Botosan, 1997).

Issues of disclosure have been relevant to a developing country like Ghana on the aftermath of the rationalisation of the banking industry by the central bank which ensued in 2017 and 2018 to sanitise and strengthen the banking sector. The rationalisation of the banking sector resulted in some banks been merged whereas other banks had their licences revoked and this may have raised doubts among investors as well as other stakeholders with regards to quality of details disclosed by these banks. The recent collapse of several operating banks in Ghana has triggered the need to assess the level of voluntary details disclosure by these banks. However, previous studies have not made a thorough assessment on the extent to which listed banks operating in Ghana voluntarily disclose information in their annual report on the aftermath of the central bank's rationalisation of the banking industry. For this reason, there is a massive information gap and this study fills that gap by assessing the level of voluntary details disclosure by listed banks operating in Ghana and proceeds to determine the variations in the types of voluntary details disclosure by listed banks operating in Ghana.
The purpose of this study is to provide empirical evidence on the extent to which listed operating banks in Ghana voluntarily disclose details in their annual reports and the variations in the types of voluntary details disclosed to assist potential shareholders and other accounting users in making informed economic decisions.

This study is significant since it provides a major extension to already existing literature on voluntary disclosure by way of measuring the variations in the types of voluntary details disclosed by listed operating banks in Ghana on the aftermath of the banking sector rationalisation by the central bank which resulted in the collapse of the sixteen (16) banks.

\section{Literature review}

This study reviewed available literature to examine empirical research on disclosures of companies and what other researchers say with regards to recent level of disclosures in firm's annual reports.

\subsection{Overview of Bank of Ghana}

Bank of Ghana (BOG), owned entirely by the Ghana Government executes its functions under the Bank of Ghana Act, 2002 (Act 612) (as amended by the Bank of Ghana (Amendment) Act, 2016 (Act 918)), Banks and Specialised Deposit-Taking Institution Act, 2016 (Act 930) and the Public Financial Management Act, 2016 (Act, 921) undertook the recapitalization of banks in 2018 and the outcome showed a total of 23 banks meeting the minimum requirement, comprising 14 foreigncontrolled banks and 9 domesticallycontrolled banks. Whereas several stakeholders believe that the measures taken by $\mathrm{BOG}$ have reduced the confidence 
stakeholders have in the banking sector, other stakeholders have different views.

\subsection{The Ghana Stock Exchange (GSE)}

The Ghana Stock Exchange executes its functions under Ghana's Companies Code, 1963 (Act 179). The objectives and functions the Ghana Stock Exchange among others are to set up the space and structure for the public to buy and sell securities.

It is believed that companies get listed on the stock market because of their desire to raise capital and also have the advantage of boosting their public image. Available data on the website of the Ghana Stock Exchange (2019) displayed 42 listing equities made up of companies from consumer goods and service, oil \& gas, technology, medical service, telecommunication and financial institutions among others. Financial institutions are made up of 12 companies of which 9 of them are banks. However, only 8 out of the 9 banks listed on the Ghana Stock Exchange are operational in Ghana. Among these are Access Bank Ghana, Agricultural Development Bank, CAL Bank Ltd, Ecobank Ghana Ltd, GCB Bank Ltd, Republic Bank Ghana Ltd, Societe Generale Ghana Ltd and Standard Chartered Bank Ghana Ltd. The Trust Bank (Gambia) is the other listed bank but not operational in Ghana.

\subsection{Theoretical review}

Theories influencing voluntary disclosure in corporate reporting are agency theory, capital need theory and signalling theory.

\subsection{Agency theory}

Agency theory enumerates the relationship between agent and principal. The corporate management (agent) are working on shareholders (principal) behalf and must therefore ensure that their actions are on the side of shareholders and the firm (Jensen \& Meckling 1976; Morris 1987). Agency problem exist where corporate management are inclined to execute actions in their self-interests inconsistent with that of shareholders leading to information asymmetry (Jensen \& Meckling 1976). Adequate disclosures on financial, strategy and non-monetary information in corporate reporting will therefore serve as a measure to control the activities of corporate management and lessen information asymmetry problem as well as agency cost (Ball \& Foster, 1982; Jensen \& Meckling, 1976; Morris, 1987; Barako, Hancock \& Izan, 2006).

The agency theory is relevant to the study since corporate management are required to disclose adequate and relevant information relating to financial, strategy and non-financial in corporate reporting for shareholders and other accounting information users to ensure swift reduction of information asymmetry problem.

\subsection{Capital need theory}

Capital need theory is concerned with firms' motivation to raise capital (either equity or debt) at a low cost and mentions that, a firm's wish to raise capital from the capital market would encourage it to make adequate voluntary disclosure in corporate reporting (Choi 1973; Cooke 1989a). Voluntary disclosure reduces capital cost and enhances shares purchase. For this reason, corporate entities must see the need 
to disclose adequate voluntary details in their reporting to entice potential shareholders (Choi, 1973; Firth, 1980; Healy, Hutton \& Palepu, 1999; Diamond \& Verrecchia, 1991; Botosan, 1997).

The capital need theory is relevant to this study because corporate management of listed banks operating in Ghana have the desire to raise money from capital market. As such, there is the need for corporate management to provide relevant voluntary details in corporate reporting to attract potential shareholders.

\subsection{Signalling theory}

Signalling theory in corporate reporting explains voluntary disclosure as a condition to reduce the problem of information asymmetry (Ross, 1977). Companies competing for capital from investors lean on adequate disclosure of voluntary information in corporate reporting as a way of signalling investors and other users of their excellence, comparable to other companies to attract investors (Verrecchia, 1983; Campbell, Shrives \& Saager, 2001). The problem of information asymmetry is reduced when corporate management decide not to hide specific information needed by users.

The signalling theory is relevant to the study since corporate management of listed banks operating in Ghana wish to enhance their company's credibility. As such they would signal investors and other accounting information users by way of providing adequate voluntary details in their reporting with regards to their excellence.

\section{7. Strategic details}

Companies provide strategic details in corporate reporting to disclose what they seek to achieve in the short run and long run. Strategic details have become relevant in voluntary disclosure studies since they furnish potential shareholders and other accounting information users with details concerning the long-term planning, directions of the firm and information needed for a firm to achieve its business objectives.

Meek, Roberts and Gray (1995) in their study developed 85 voluntary disclosure items to include 23 strategic information items whilst de la Bruslerie and Gabteni (2010) included 22 strategic information in their study. United Nations Conference on Trade and Development (UNCTAD, 2017) case study of Itaú Unibanco also provided 14 strategic information.

\section{8. Non-financial details}

Non-financial details used in view of this context is concerned with any information provided in corporate reporting discounting financial details that are not quantified in monetary terms. Disclosure of non-financial detail is relevant to voluntary disclosure studies because it is believed to provide transparent and more interesting information in corporate reporting.

Meek et. al (1995) included 27 nonfinancial information whilst de la Bruslerie and Gabteni (2010) included 3 non-financial information items in their study. UNCTAD (2017) on the other hand included 6 nonfinancial information items in the case study of Itaú Unibanco.

\subsection{Financial details}

Financial detail used in this context is concerned with information such as firm's 
assets, liabilities, equity that can be found in the annual report. Financial details are essential to disclosure studies since they provide information on financial capabilities of corporate entities for potential shareholders and other accounting information users.

Meek et. al (1995) included 35 information items in their study whilst de la Bruslerie and Gabteni (2010) included 15 financial information items in their study. UNCTAD (2017) however included only value added statement as financial information in the case study of Itaú Unibanco.

\subsection{Empirical review}

A number of prior studies such as (Cerf, 1961; Copeland and Fredericks, 1968; Singhvi and Desai, 1971; Buzby, 1975; Firth, 1979 and 1980; Chow and Wong-Boren, 1987; Cooke (1989a and $1989 \mathrm{~b}$ etc.) and current studies researchers (such as, Gray et. al., 1995; Meek et. al., 1995; Botosan, 1997; Botosan and Plumlee, 2002; de la Bruslerie and Gabteni, 2010; Iatridis and Valahi, 2010; Murcia and Santos, 2012; Consoni and Colauto, 2016 etc). have examined literature on disclosure.

Cerf (1961) was the foremost researcher to employ a disclosure index on voluntary disclosure by building an index comprising of 31 details from the annual reports.

Researchers like Copeland and Fredericks (1968), Singhvi and Desai (1971), Buzby (1975), Firth (1979; 1980), Chow and Wong-Boren (1987), Cooke (1989a) were inspired by Cerf's work and adopted his ideas in their research because they found his technique useful.

Whilst Copeland and Fredericks (1968) used 6 specific indices of 200 NYSE firms for the year 1964, Singhvi and Desai (1971) in their study selected 34 voluntary disclosure items, Buzby (1975) develop an index of 39 items of financial and nonfinancial details for 44 NYSE and American Express Company (AMEX) firms plus 44 OTC firms annual reports (from $30^{\text {th }}$ June, 1970 to $30^{\text {th }}$ June, 1971). Firth (1979 and 1980) however developed 48 items for 40 non-listed producing entities and 100 listed producing entities' annual reports for the year 1976 and Chow and Wong-Boren (1987) developed 24 items for the annual reports of 52 Mexican Stock Exchange firms for 1982 period.

Cooke (1989a and 1989b) on the other hand developed 224 items and 146 items respectively for 90 entities in Sweden for the 1985 period and confirms that 'listing status and size' explain the extent of disclosure and also finds that 'listing status and size' are important explanatory variables for voluntary disclosure whereas trading entities disclose little voluntary details as compared to industrial entities.

Gray, Meek and Roberts (1995) developed 128 items for 116 U.S., 64 U.K., Multinational Corporation (MNCs) and 100 Continental European multinational entities for the year 1989 find a substantial variation in corporate reporting between 'internationally listed and domestically listed firms.'

Meek et. al. (1995) developed 85 listings for annual reports of 116 U.S., 64 U.K., Multinational Corporation (MNCs) 
and 46 Continental European Multinational Corporations (MNCs) and find that Continental European Multinational Corporations (MNCs) provide improved voluntary details as compared to American or British MNCs. Size of entities, country of operation, and 'international listing status' are significant to explain the voluntary disclosure of firms. However, leverage, multinationality and profitability variable are not statistically significant.

Botosan (1997) sampled 122 producing entities and examined their 1990 annual reports and confirms that enhanced disclosure is related to 'lower cost of equity capital'. However, the study reveals no evidence of relationship between disclosure level and 'cost of equity capital'.

Botosan and Plumlee (2002) used 3,623 observations involved in AIMR Reports from 1985/86 and 1995/96 periods. Their study indicates that managers of entities that produce enhanced disclosure in the annual report benefit as result of 'lower cost of equity capital and that timely improved disclosure is related to 'higher cost of equity capital'. However, the study reveals no relationship between the 'cost of equity capital and the level of investor relations' activities.

de la Bruslerie and Gabteni (2010) developed 28 items for 120 listed French firms from 2003-2008 and find that detailed disclosure improved substantially from 2003-2008 and firms that have the ability to communicate reduce information asymmetry as the extent of information vary among analysts' expectations of companies growth and profitability.

Iatridis and Valahi (2010) used 262
UK entities listed on the London stock market for pre-official adoption period of 2004 and find entities that voluntarily disclose details appear to voluntarily adopt IAS 1 and that 'leverage, profitability, liquidity and growth', influence judgements to approve voluntary accounting policy or regulation.

Murcia and Santos (2012) developed 92 voluntary items and presented 3 disclosure models: 'economic, socioenvironmental and total (economic and socio-environmental)' for the annual reports of 100 biggest non-financial entities listed in the 'Bolsa de Valores de São Paulo ('Brazilian Securities, Commodities, and Futures exchange - BOVESPA)' for the period 2006-2008 and find that profitability is important in the economic model and in the 'total model' but 'leverage and auditing firm' are only important in the 'economic disclosure model'. However, 'Size, Governance, Stock Issuing, Growth Opportunities and Concentration of Control' are insubstantial to the 3 models.

Consoni and Colauto (2016) developed 27 items for 66 active in BM\&FBovespa companies during the 2005-2012 period and find that voluntary disclosure in Brazil was influenced substantially by mandatory disclosure in the process of convergence to international accounting.

Several prior studies and current studies researchers have extensively examined the literature on disclosure. However, these studies fall short to address the level of voluntary disclosure of listed firms operating in Ghana as well as research on the variations in the types of voluntary details disclosed by listed banks operating in 
Ghana on the aftermath of the central bank's rationalisation of the banking industry. This study therefore fills this gap by examining the level of voluntary disclosure of listed banks operating in Ghana in the annual reports for 2018 accounting year and advance to determine whether there are no significance variations in the types of voluntary details disclosed by listed banks operating in Ghana.

\subsection{Conceptual design}

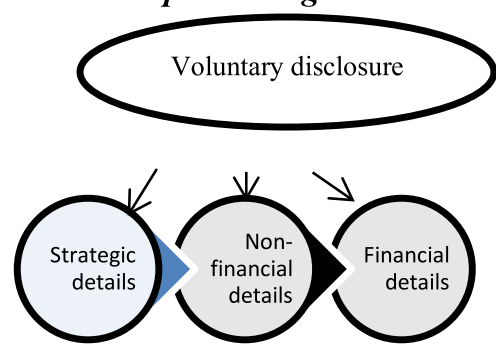

Figure 1. Paradigm revealing the connection between voluntary disclosure and its measuring variables.

\section{Methodology}

The study employed quantitative research design in gathering and analysing the data. As indicated earlier, there are 23 banks in Ghana currently comprising of 14 foreign-controlled banks and 9 domestically-controlled banks. Out of the 23 banks only 9 banks are listed on the Ghana Stock Exchange but only 8 are operational in Ghana. Purposive sampling was used in selecting all the 8 banks listed on the Ghana Stock Exchange and operating in Ghana. Listed banks operating in Ghana were chosen because of their desire to raise capital for their businesses from the stock market and also because of their advantage to boost their public image by getting listed on the stock market. It is then expected that, listed banks operating in Ghana disclose adequate voluntary details in their annual report to attract potential shareholders.

The annual reports obtained from the various companies' website for the year 2018 were assessed to assist in this study to determine the level of voluntary details disclosed by the banks. The annual report for the year 2018 was selected because it is fairly current and relevant to this study on the aftermath of the banking industry rationalisation.

Several researchers have developed their own voluntary disclosure index to assess the level of disclosure made by firms using either weighted disclosure indexes or unweighted disclosure index since there is currently no universally accepted voluntary disclosure index. Different weights are applied to the same item of information for all firms under weighted disclosure whereas unweighted disclosure approach use either dichotomous approach or modified dichotomous approach to attach different weights to applicable item of information for all firms. Several researchers have criticized the use of weighted index approach because certain information relevant to some companies might not be applicable and relevant to other companies. In such case, it would not be appropriate to use the same weight for all companies (Cooke 1992). This study however adopted the modified dichotomous approach under unweighted index by Cooke (1989a; 1989b and1992) since it is appropriate to this study because Chow and Wong-Boren (1987) opined that users get the chance to make an independent analysis of this method and also require users to read the corporate annual reports wholly to overcome any potential bias. Cooke (1989a; 1991 and 1992) also argued that, 
unweighted disclosure index approach is appropriate since it does not use the same weight for all companies and reduces the impact of the subjective weights among the various user groups.

The disclosure index developed in previous research consists of a variety of items that can be used to provide scores to influence economic decision needs of users.

A disclosure checklist was developed based on prior studies (such as Cooke, 1989a), current studies (such as Meek et. al., 1995; Botosan, 1997; de la Bruslerie and Gabteni, 2010), and an examination of international trends and standard reporting practices (such as UNCTAD, 2017) and also based on guarded consideration of entity's complete annual report consisting of financial statements, information on corporate governance, information on business review, shareholders information and corporate information among other. The disclosure checklist of 118 voluntary disclosure items (categorized into 3 namely strategic details, non-financial details and financial details) have been developed for this study considering the interest of the various user groups. Several researchers (such as Cooke 1992; Marston and Shrives 1991 etc.) have posited that the development of disclosure index can be subjective since annual reports have numerous user groups with different needs. For instance investors are concerned with information in relation to profitability and earnings rate of return while employees are concerned with information in relation to workplace conditions and compensation packages. This study has therefore made an extensive effort to reduce subjectivity by developing an index of disclosure items that are relevant to all range of users of accounting information. This is due to the fact that users' information needs are broad and some specific information meant for employees or any other user might also be relevant to potential shareholders and other users. The strategic details which disclose information on what the entities seek to achieve in the short run and long run is represented by general corporate details ( 25 items developed), corporate strategy (17 items developed), research and development ( 3 items developed) and future prospects ( 8 items developed). The nonfinancial details which disclose information that are not quantified in monetary terms is represented by details on directors (7 items developed), details on employees (13 items developed) and social policy details (6 items developed). The financial details which disclose information such as firm's assets, liabilities, equity in the annual report is represented by segment details (17 items developed), financial review (14 items developed), foreign currency information (3 items developed) and stock price details (5 items developed).

Table 1. Operationalization of the variables Dependent variable

TD Total disclosure

Independent variable

Item Strategic details

Non-financial details

Financial details

The voluntary disclosure index

(VDI) unweighted index (modified dichotomous approach) is calculated by dividing overall voluntary disclosure items a firm disclose by number of applicable voluntary disclosure items. 
VDI = Actual disclosure by a firm / Total possible disclosure. This is shown as;

Where, $\quad V D I=\sum_{i=1}^{m} d i / \sum_{i=1}^{n} d i$

$\mathrm{d}=$ score 1 if item $d i$ is disclosed and score

0 if item $d i$ is not disclosed,

$\mathrm{m}=$ overall items disclosed by a firm,

$\mathrm{n}=$ overall voluntary disclosure items which

the company is expected to disclose, i.e.

$\mathrm{n} \leq 118$. This study assessed the various listed banks using the researcher's own scoring guidelines for the means as follows; 0.80 and above $=$ excellent, $0.70-0.79=$ above average, $0.60-0.69=$ slightly above average, $0.50-0.59=$ average, $0.40-0.49=$ below average and 0.39 and below $=$ poor.

\section{1. Hypothesis}

This study assumes that there are no significant variations in the type of voluntary details disclosed by listed banks operating in Ghana. To confirm this, one way ANOVA was performed to test hypothesis of no significant differences in the type of information voluntarily disclosed by listed banks in Ghana as Gray et. al., (1995) used ANOVA for the purposes of statistical analysis in their study. Before oneway ANOVA was performed, the assumption of normality was evaluated using Kolmogorov-Smirnov test to check for normality of the three disclosure groups. Also, Levene's test was used to test for homogeneity of variances to ensure variances for the three groups are the same for the test to give a valid result. Eta squared was computed (Eta squared $=$ Sum of squares between groups/Total sum of squares) to determine the effect size using Cohen (1988) guidelines of $0.01=$ less effect, $0.06=$ intermediate effect and $0.14=$ great effect. To evaluate the nature of the differences between the 3 groups made up of strategic details, non-financial details and financial details, the Tukey post hoc test was used to measure the statistically significant differences between the 3 groups.

The ANOVA model is specified as:

$\mathrm{yqj}_{\mathrm{q}}=\mu_{\mathrm{j}}+\varepsilon_{\mathrm{qj}}$

Where,

$\mathrm{y}_{\mathrm{q}}=$ observations or dependent variable, $\mathrm{q}=1, \ldots \ldots, \mathrm{q}$ represents an index over within groups, $\mathrm{j}=1, \ldots \ldots, \mathrm{j}$ represents an index over between groups,

$\mu_{j}=$ the mean of the observations for the jth between groups, $\varepsilon=$ unobserved random error with 0 mean. F statistic would be computed as;

$\mathrm{F}=\mathrm{MeSG} / \mathrm{MeSE}$

Where MeSG = Mean square between groups, $\mathrm{MeSE}=$ Mean square within groups. 


\section{0. Results and discussion}

Table 2: Level of voluntary disclosures among listed banks in Ghana (mean scores)

\begin{tabular}{|c|c|c|c|c|c|c|c|c|}
\hline $\begin{array}{c}\text { Voluntary } \\
\text { disclosure } \\
\text { items } \\
\end{array}$ & $\begin{array}{l}\text { Access } \\
\text { Bank } \\
\text { Ghana }\end{array}$ & $\begin{array}{l}\text { Agricultural } \\
\text { Development } \\
\text { Bank }\end{array}$ & $\begin{array}{l}\text { CAL } \\
\text { Bank } \\
\text { Ltd }\end{array}$ & $\begin{array}{l}\text { Ecobank } \\
\text { Ghana } \\
\text { Ltd }\end{array}$ & $\begin{array}{l}\text { GCB } \\
\text { Bank } \\
\text { Ltd }\end{array}$ & $\begin{array}{l}\text { Republic } \\
\text { Bank } \\
\text { Ghana } \\
\text { Ltd } \\
\end{array}$ & $\begin{array}{l}\text { Societe } \\
\text { Generale } \\
\text { Ghana Ltd }\end{array}$ & $\begin{array}{l}\text { Standard } \\
\text { Chartered } \\
\text { Bank Ghana } \\
\text { Ltd }\end{array}$ \\
\hline GCD & 0.9200 & 0.6959 & 0.6250 & 0.8800 & 0.7083 & 0.7917 & 0.6800 & 0.8400 \\
\hline CSD & 1.0000 & 0.6471 & 0.7647 & 0.7647 & 0.7059 & 1.0000 & 0.6471 & 0.8824 \\
\hline $\mathrm{R} \& \mathrm{D}$ & 0.0000 & 0.6667 & 0.0000 & 0.0000 & 0.0000 & 0.0000 & 0.0000 & 0.0000 \\
\hline FPD & 0.3750 & 0.2500 & 0.2500 & 0.2500 & 0.3750 & 0.2500 & 0.2500 & 0.2500 \\
\hline StD & 0.8113 & $\mathbf{0 . 6 0 7 8}$ & 0.5769 & 0.6981 & 0.6154 & 0.6346 & 0.5660 & 0.7170 \\
\hline DoD & 0.8571 & 1.0000 & 1.0000 & 1.0000 & 0.8571 & 1.0000 & 1.0 & 1.0000 \\
\hline DoE & 0.8 & 0.3 & 077 & 0.3846 & 0.31 & 0.2 & 0.3 & 0 \\
\hline SPD & 0.8333 & 0.3333 & 0.8333 & 0.8333 & 0.8333 & 0.6667 & 0.5000 & 0.8333 \\
\hline NFD & 0.8462 & $\mathbf{0 . 5 3 8 5}$ & 0.6154 & 0.6538 & 0.5769 & 0.5385 & 0.5769 & 0.8462 \\
\hline $\mathrm{SeD}$ & 0.4118 & 0.4118 & 0.4706 & 0.3524 & 0.4706 & 29 & 0. & 0 \\
\hline FRD & 0.4286 & 0.6429 & 0.7143 & 0.7143 & 0.5714 & 0.5714 & 0.5000 & 0.7143 \\
\hline FCD & 1.0000 & 1.0000 & 1.0000 & 1.0000 & 1.0000 & 1.0000 & 1.0000 & 1.0000 \\
\hline StPD & 0.8000 & 0.8000 & 1.0000 & 0.8000 & 1.0000 & 0.8000 & 0.8000 & 0.8000 \\
\hline FD & 0.5128 & 0.5897 & 667 & & .6154 & 0.5385 & 0.5385 & 0.6154 \\
\hline TD & 0.7203 & 0.5862 & 154 & 525 & 6068 & 0.5812 & 0.5593 & 0.7119 \\
\hline
\end{tabular}

Source: Authors computation from 2018 annual reports. Table 2 revealed that Access Bank Ghana Ltd had the highest level of disclosure with mean of 0.8113 for strategic information followed by Standard Chartered Bank Ghana Ltd with mean of 0.717. This suggests that Access Bank Ghana Ltd and Standard Chartered Bank Ghana Ltd disclosed more information under strategic details than the other listed banks. Ecobank Ghana Ltd was ranked next with mean of 0.6981 followed by Republic Bank Ghana Ltd with mean of 0.6346. It was then followed by GCB Bank Ltd with mean of 0.6154. Agricultural Development Bank followed closely with mean of 0.6078 , followed by CAL Bank Ltd with mean of 0.5769. The results revealed that, Ecobank Ghana Ltd, Republic Bank Ghana Ltd, GCB Bank Ltd and Agricultural Development Bank means are slightly above average per the researcher's level of voluntary disclosure scoring guidelines. Next was Societe General Bank Ltd with mean of 0.5660. The implication is that, Access Bank Ghana Ltd and Standard Chartered Bank Ghana recognized the provision of information concerning the long-term planning, directions of the firm and information needed for the firm to achieve its business objectives as the way forward to boost the confidence of investors and other users of 
accounting information. Ecobank Ghana Ltd, Republic Bank Ghana Ltd, GCB Bank Ltd, Agricultural Development Bank, CAL Bank Ltd and Societe General Bank Ltd also did acknowledge the importance of providing strategic details.

Non-financial details in table 2 revealed that Access Bank Ltd and Standard Chartered Bank Ghana Ltd had the highest level of disclosure with means of 0.8462 each. This outcome indicates that Access Bank Ltd and Standard Chartered Bank Ghana Ltd were more concerned with nonfinancial details as compared to the other listed banks. This also implies that Access Bank Ltd and Standard Chartered Bank Ghana Ltd were more transparent in their reporting to restore confidence in investors and other users of accounting information. Ecobank Ghana Ltd followed with mean of 0.6538. Next was CAL Bank Ltd with mean of 0.6154. Ecobank Ghana Ltd and CAL Bank Ltd means are slightly above average per the researcher's level of voluntary disclosure scoring guidelines. Next were GCB Bank Ltd and Societe General Bank Ltd with means of 0.5769 each, followed by Agricultural Development Bank and Republic Bank Ghana Ltd with a mean of 0.5385 each. This finding implies that Ecobank Ghana Ltd, CAL Bank Ltd, GCB Bank Ltd, Societe General Bank Ltd, Agricultural Development Bank and Republic Bank Ghana Ltd did acknowledge the prominence of providing non-financial details in their annual report though, Ecobank Ghana Ltd and CAL Bank Ltd means were slightly above average whereas GCB Bank Ltd, Societe General Bank Ltd, Agricultural Development Bank and Republic Bank Ghana Ltd means were average.

Disclosure on Financial details in table 2 revealed that, CAL Bank Ltd had highest level with mean of 0.6667 , followed by GCB Bank Ltd and Standard Chartered Bank Ghana Ltd with means of 0.6154 each. CAL Bank Ltd, GCB Bank Ltd and Standard Chartered Bank Ghana Ltd means were slightly above average per the researcher's level of voluntary disclosure scoring guidelines. Next were Agricultural Development Bank and Ecobank Ghana Ltd with means of 0.5897 each. It was then followed by Republic Bank Ghana Ltd and Societe General Bank Ltd with means of 0.5385 each. Next was Access Bank Ltd with a mean of 0.5128. Agricultural Development Bank and Ecobank Ghana Ltd, Republic Bank Ghana Ltd and Societe General Bank Ltd means were average per the researcher's level of voluntary disclosure scoring guidelines. This finding suggests that, CAL Bank Ltd disclosed more information under financial details than the other listed banks. CAL Bank Ltd, GCB Bank Ltd, Standard Chartered Bank Ghana Ltd, Agricultural Development Bank, Ecobank Ghana Ltd, Republic Bank Ghana Ltd, Societe General Bank Ltd and Access Bank Ltd did acknowledge the importance of providing adequate financial details in their annual reports. The implication is that, these banks admitted the important role adequate financial details play in communicating a firm's financial performance to potential shareholders and other accounting information users, which essentially would boost the confidence of potential shareholders and other accounting information users. 
Table 3: Rank of overall disclosure level for listed banks operating in Ghana

\begin{tabular}{lccl}
\hline BANK & MEAN & RANK & REMARKS \\
\hline Access Bank Ghana Ltd & $\mathbf{0 . 7 2 0 3}$ & $1^{\text {st }}$ & Above average \\
Standard Chartered Bank Ghana Ltd & $\mathbf{0 . 7 1 1 9}$ & $2^{\text {nd }}$ & Above average \\
Ecobank Ghana Ltd & $\mathbf{0 . 6 5 2 5}$ & $3^{\text {rd }}$ & Slightly above average \\
CAL Bank Ltd & $\mathbf{0 . 6 1 5 4}$ & $4^{\text {th }}$ & Slightly above average \\
GCB bank Ltd & $\mathbf{0 . 6 0 6 8}$ & $5^{\text {th }}$ & Slightly above average \\
Agricultural Development Bank & $\mathbf{0 . 5 8 6 2}$ & $6^{\text {th }}$ & Average \\
Republic Bank Ltd & $\mathbf{0 . 5 8 1 2}$ & $7^{\text {th }}$ & Average \\
Societe General Bank Ltd & $\mathbf{0 . 5 5 9 3}$ & $8^{\text {th }}$ & Average \\
TOTAL DISCLOSURE & $\mathbf{0 . 6 2 9 4}$ & & Slightly above average
\end{tabular}

Source: Authors computation from 2018 annual reports.

Table 3 revealed an overall total disclosure level mean of 0.6294 for the listed banks operating in Ghana for the 2018 period which was slightly above average. Access Bank Ghana Ltd was ranked first with overall disclosure mean of 0.7203 followed by Standard Chartered Bank Ghana Ltd with mean of 0.7119. Ecobank Ghana Ltd placed third with mean of 0.6525 , CAL Bank Ltd fourth with mean of 0.6154, GCB bank Ltd placed fifth with a mean of 0.6068, Agricultural Development Bank placed sixth with mean of 0.5862 , Republic Bank Ltd placed seventh with mean of 0.5812 , Societe General Bank Ltd placed eighth with mean of 0.5593 . This shows that Access Bank Ghana Ltd and Standard Chartered Bank Ghana Ltd means were above average whereas Ecobank Ghana Ltd, CAL Bank Ltd, GCB bank Ltd means were slightly above average and Agricultural Development Bank, Republic Bank Ltd, Societe General Bank Ltd means were average per the researcher's level of voluntary disclosure scoring guidelines. The implication is that all the 8 listed banks operating in Ghana demonstrated their desire to generate capital from investors in the capital market by providing voluntary details in their annual reports for the 2018 period. This is consistent with the assertions of Choi, 1973; Firth, 1980; Cooke, 1989a; Healy et al., 1999; Diamond and Verrecchia, 1991; Botosan, 1997 and also consistent with the agency theory, capital need theory and signalling theory.

Table 4: Tests of Normality

\begin{tabular}{lcccccc}
\hline & \multicolumn{3}{c}{ Kolmogorov-Smirnov ${ }^{\mathrm{a}}$} & \multicolumn{3}{c}{ Shapiro-Wilk } \\
& Statistic & Df & Sig. & Statistic & Df & Sig. \\
\hline Total_Disclosure & .163 & 117 & .065 & .939 & 117 & .115 \\
\hline
\end{tabular}

Source: Source: Authors computation from SPSS version 21.

Table 4 revealed that, the assumption of normality for the 3 groups of disclosure has been met since the significance value is 0.065 which is greater than 0.05 . 
Table 5: Test of Homogeneity of Variances

\begin{tabular}{llll}
\hline Levene Statistic & df1 & df2 & Sig. \\
\hline 2.124 & 2 & 115 & .124 \\
\hline
\end{tabular}

Source: Authors computation from SPSS version 21.

Test for homogeneity of variance in table 5 revealed that the significance value (Sig. $=$ 0.124 ) is greater than 0.05 . This is an indication that the variances in scores are the same for each of the three groups made up of strategic details, non-financial details and financial details. This means the ANOVA is considered robust since the requirement of homogeneity has been met.

Table 6: Descriptive statistics

\begin{tabular}{|c|c|c|c|c|c|c|c|c|}
\hline & $\mathrm{N}$ & Mean & $\begin{array}{l}\text { Std. } \\
\text { Deviation }\end{array}$ & $\begin{array}{l}\text { Std. } \\
\text { Error }\end{array}$ & $\begin{array}{l}95 \% \text { Confide } \\
\text { for Mean } \\
\text { Lower } \\
\text { Bound }\end{array}$ & $\begin{array}{l}\text { ence Interval } \\
\text { Upper } \\
\text { Bound }\end{array}$ & $\begin{array}{l}\text { Minimu } \\
\mathrm{m}\end{array}$ & $\begin{array}{l}\text { Maxim } \\
\text { um }\end{array}$ \\
\hline $\begin{array}{l}\text { Strategic } \\
\text { details }\end{array}$ & 53 & .6534 & .39356 & .05406 & .53775 & .75471 & .00 & 1.00 \\
\hline $\begin{array}{l}\text { Non-Financial } \\
\text { details }\end{array}$ & 26 & .6490 & .33170 & .06505 & .51506 & .78301 & .00 & 1.00 \\
\hline $\begin{array}{l}\text { Financial } \\
\text { details }\end{array}$ & 39 & .5833 & .43992 & .07044 & .44073 & .725934 & .00 & 1.00 \\
\hline Total & 118 & .6286 & .39511 & .03637 & .55402 & .69810 & .00 & 1.00 \\
\hline
\end{tabular}

Source: Authors computation from SPSS version 21.

Descriptive statistics in Table 6 revealed a numerical difference between the means for the 3 groups (that is $\mathrm{M}=0.6534$ for strategic details, $\mathrm{M}=0.6490$ for nonfinancial details and $\mathrm{M}=0.5833$ for financial details). This suggests that listed banks in Ghana disclosed more information under strategic details as compare to non-financial and financial details for the 2018 period. This is interesting to assume that, listed banks operating in Ghana had a big craving for strategic details and demonstrated that strategic details were more appealing to restore confidence in potential shareholders and other accounting information users than non-financial and financial information. Listed banks operating in Ghana on the other hand disclosed more information under nonfinancial details than financial details. This is also right to assume that, listed banks operating in Ghana had an intense craving for non-financial details than financial details and gave credence to the fact that non-financial details included in their 2018 annual reports were more attractive to potential shareholders and other accounting information users than financial details. Though there were numerical differences between the means for the 3 groups, there is no enough evidence to conclude that the differences in means for the type of information voluntarily disclosed by listed banks in Ghana are not significant. Therefore, one way ANOVA was performed to test hypothesis of no significant differences in the type of information voluntarily disclosed by listed banks in Ghana. 
Table 7: ANOVA table

\begin{tabular}{llllll}
\hline & Sum of Squares & Df & Mean Square & F & Sig. \\
\hline Between Groups & 1.078 & 2 & .539 & 6.377 & .003 \\
Within Groups & 7.183 & 115 & .085 & & \\
Total & 8.261 & 117 & & &
\end{tabular}

Source: Authors computation from SPSS version 21.

ANOVA table is presented in table 7. The F test of 6.377 in the ANOVA table revealed that at least one of the independent variables has a significant difference. The significance value is 0.003 (i.e., $p=0.003$ ), which is below 0.05 shows a statistical significant difference between strategic details, non-financial details and financial details. The effect size associated with statistically significance difference between groups calculated using Eta squared shows an effect size of 0.130 which indicates an intermediate effect according to Cohen (1988) guidelines. Therefore, the null hypothesis of no significant differences in the type of voluntary details disclosed by listed banks operating in Ghana is rejected. Since the ANOVA table did not show which specific groups differed, the Tukey post hoc test was used to measure the statistically significant differences between strategic details, non-financial details and financial details.

Table 8: Tukey HSD Multiple Comparisons

\begin{tabular}{|c|c|c|c|c|c|c|}
\hline \multirow[t]{3}{*}{ (I) Item } & \multirow[t]{3}{*}{ (J) Item } & Mean & Std. & Sig. & \multicolumn{2}{|c|}{$95 \%$ Confidence Interva } \\
\hline & & Difference & Error & & Lower & Upper \\
\hline & & $(\mathrm{I}-\mathrm{J})$ & & & Bound & Bound \\
\hline \multirow{2}{*}{ Strategic details } & Non-financial details & -.22477 & .07850 & .014 & -.4120 & -.0375 \\
\hline & Financial details & -.23382 & .07267 & .005 & -.4072 & -.0605 \\
\hline \multirow{2}{*}{ Non-financial details } & Strategic details & .22477 & .07850 & .014 & .0375 & .4120 \\
\hline & Financial details & -.00905 & .07850 & .993 & -.1963 & .1782 \\
\hline \multirow{2}{*}{ Financial details } & Strategic details & .23382 & .07267 & .005 & .0605 & .4072 \\
\hline & Non-financial details & .00905 & .07850 & .993 & -.1782 & .1963 \\
\hline
\end{tabular}

Source: Authors computation from SPSS version 21.

The Tukey post hoc test in table 8 revealed a statistical significant difference between strategic details and non-financial details with $p$ value of 0.014 (i.e., $p=0.014$ ) which is below 0.05 . This suggests a measurable difference between strategic details and Non-financial details. This shows that the difference in mean for strategic details and Non-financial details was substantial to conclude that, the difference was very unlikely to be due to chance. This confirms the assumption that listed banks operating in Ghana had a big craving for strategic details and 
demonstrated that strategic details were more appealing to restore confidence in investors and other users of accounting information than non-financial details in their 2018 annual reports.

There is also a statistical significant difference between strategic information and financial information with $\mathrm{p}$ value of 0.005 (i.e., $\mathrm{p}=0.005$ ) which is also below 0.05 . This shows that the difference in mean between strategic details and financial details is appreciable to conclude that, the difference was very unlikely to be due to chance. This confirms the assumption that that listed banks in Ghana had an intense craving for strategic details than financial details and gave credence to the fact that strategic details included in their 2018 annual reports were more attractive to potential shareholders and other users of accounting information than financial details. However, there is no statistical significant difference between non-financial details and financial details since the $\mathrm{p}$ value of 0.993 (i.e., $p=0.993$ ) is greater than 0.05 .

\section{Conclusion}

The study assessed the level of voluntary details disclosed by listed banks operating in Ghana in their annual reports for the 2018 period and also determined the variations in the types of information voluntarily disclosed by listed banks in Ghana. The overall total voluntary disclosure level mean of 0.6294 is an indication that voluntary disclosure level among listed banks operating in Ghana was slightly above average (per the researcher's level of voluntary disclosure guidelines). Access Bank Ghana Ltd made the highest level of overall voluntary disclosure with mean of 0.7203 followed by Standard
Chartered Bank Ghana Ltd with mean of 0.7119. Ecobank Ghana Ltd followed with mean of 0.6525 , then CAL Bank Ltd with mean of 0.6154. GCB bank Ltd was next with mean of 0.6068 , followed by Agricultural Development Bank with mean of 0.5862. Republic Bank Ltd was next with mean of 0.5812 , and followed by Societe General Bank Ltd with mean of 0.5593. Access Bank Ghana Ltd had the highest voluntary disclosure with mean of 0.8113 for the strategic details followed by Standard Chartered Bank Ghana Ltd with mean of 0.7170. Access Bank Ghana Ltd and Standard Chartered Bank Ghana Ltd means were 0.8462 each for non-financial details. However CAL Bank Ltd had the highest mean of 0.6667 for financial details followed by GCB Bank Ltd and Standard Chartered Bank Ghana Ltd with means of 0.6154 each. Agricultural Development Bank and Ecobank Ghana Ltd followed next with means of 0.5897 each. Republic Bank Ghana Ltd and Societe General Bank Ltd were next with means of 0.5385 each. Access Bank Ltd then followed with mean of 0.5128 . The results for Standard Chartered Bank Ghana Ltd which indicated mean of 0.717 for strategic details, 0.8462 for non-financial details and 0.6154 for financial details may suggest that Standard Chartered Bank Ghana Ltd disclosed more information with regards to investor's information needs than Access Bank Ghana Ltd and other listed bank. All the 8 listed banks operating in Ghana had shown their desire to raise capital from the capital market by disclosing voluntary details in their 2018 annual reports.

The Tukey post hoc test showed a statistical significant difference between strategic details and non-financial details 
and a statistical significant difference between strategic details and financial details indicating a measureable difference between the 3 groups of voluntary disclosure and confirming that listed banks operating in Ghana had a big craving for strategic details than non-financial details and financial details in the 2018 annual reports. However, there is no statistical significant difference between non-financial details and financial details.

It is recommended that adequate voluntary information comprising of strategic details, non-financial details and financial details must be provide in the annual reports of entities in need of capital from the capital market to guarantee transparency, consistency, reliability and comparability of annual reports and go on to influence the economic decision needs of potential shareholders and other accounting information users.

On that note, future research for the extent of information needs for investors as well as other accounting information users is needed.

\section{References}

Ball, R., \& Foster, G. (1982). Corporate Financial Reporting: A Methodological Review of Empirical Research. Journal of Accounting Research, 20, 161-234. doi:10.2307/2674681

Barako, D. G., Hancock, P., \& Izan, H. Y. (2006). Factors influencing voluntary corporate disclosures by Kenyan companies, Corporate Governance: An International Review, 14(2), 107-125. http://dx.doi.org/10.1111/j.14678683.2006.00491.x

Botosan, C. A. (1997). Disclosure level and cost of equity capital. The Accounting Review, 72(3), 323-349.
Botosan, C. A., \& Plumlee, M. A. (2002). A re-examination of disclosure level and the expected cost of equity capital. Journal of Accounting Research, 40(1), 21-40. https://doi.org/10.1111/1475679X.00037

Buzby, S. L. (1975). Company Size, Listed Versus Unlisted Stocks, and the Extent of Financial Disclosure. Journal of Accounting Research, 13(1), 16-37. doi: $10.2307 / 2490647$

Campbell, D., Shrives, P., \& Saager, H.B. (2001). Voluntary disclosure of mission statements in corporate annual reports: Signaling What and To Whom? Business and Society Review, 106(1), 65-87. http://dx.doi.org/10.1111/00453609.00102

Cerf, A. R. (1961), Corporate Reporting and Investment Decision, Berkeley: University of California Press.

Choi, F. D. S., \& Levich, R. M. (1990). The capital market effects of international accounting diversity. Homewood, Ill: Dow Jones Irwin.

Choi, F. D. S. (1973). Financial disclosure and entry to the European capital market. Journal of Accounting Research, 11(2), $\begin{array}{llllllll}1 & 5 & 9 & - & 1 & 7 & 5\end{array}$. http://dx.doi.org/10.2307/2490187

Chow, C. W., \& Wong-Boren, A. (1987). Voluntary financial disclosure by Mexican corporations. The Accounting Review, 62, 533-541.

Cohen, J. (1988). Statistical power analysis for the behavioral sciences (2nd ed.). Hillsdale, NJ: Lawrence Erlbaum Associates.

Consoni S., \& Colauto R. D. (2016). Voluntary disclosure in the context of convergence with International Accounting Standards in Brazil. Review of Business Management, 18 (62), 658- 
677. doi: 10.7819/rbgn.v18i62.2242

Cooke, T. E. (1989a). Disclosure in the Corporate Annual Reports of Swedish Companies. Accounting and Business Research, 19 ( 74 ), 113-124. doi:10.1080/00014788.1989.9728841

Cooke, T. E. (1989b). Voluntary Corporate Disclosure by Swedish Companies. Journal of International Financial Management \& Accounting, 1(2), 171-195. doi:10.1111/j.1467646x.1989.tb00009.x

Cooke, T. E. (1992). The Impact of Size, Stock Market Listing and Industry Type on Disclosure in the Annual Reports of Japanese Listed Corporations. Accounting and Business Research, 22 ( 87 ), $229-237$. doi:10.1080/00014788.1992.9729440

Copeland, R. M., \& Fredericks, W. (1968). Extent of Disclosure. Journal of Accounting Research, 6(1), 10-1136. doi: $10.2307 / 2490127$

de la Bruslerie, H., \& Gabteni, H. (2010). Voluntary financial disclosure, the introduction of IFRS and long-term communication policy: An empirical test on French firms. Multinational Financial Society (MFS), Barcelona, Spain. halshs-00636602.

Diamond, D., \& Verrecchia, R. (1991): Disclosure, Liquidity, and the Cost of Capital, Journal of Finance 46, 1325-60.

Firth, M. (1979). The Impact of Size, Stock Market Listing, and Auditors on Voluntary Disclosure in Corporate Annual Reports. Accounting and Business Research, 9(36), 273-280. doi:10.1080/00014788.1979.9729168

Firth, M. (1980). Raising Finance and Firms' Corporate Reporting Policies. Abacus, 16(2), 100-115. doi:10.1111/j.14676281.1980.tb00090.x
Ghana stock Exchange (2019) Listed Companies: Retrieved from https://gse.com.gh/listed-companies/

Gray, S. J., Meek, G. K., \& Roberts, C. B. (1995). International Capital Market Pressures and Voluntary Annual Report Disclosures by U.S. and U.K. Multinationals. Journal of International Financial Management \& Accounting, 6(1), 43-68. doi: 10.1111/j.1467646x.1995.tb00049.x

Healy, P. M., Hutton, A. P., \& Palepu, K. G. (1999). Stock Performance and Intermediation Changes Surrounding Sustained Increases in Disclosure. Contemporary Accounting Research, 16(3), 485-520. doi:10.1111/j.19113846.1999.tb00592.x

Healy, P. M., \& Palepu, K. G. (2001). Information asymmetry, corporate disclosure, and the capital markets: A review of the empirical disclosure literature. Journal of Accounting and Economics, 31 (1 - 3), 405-440.

Iatridis, G., \& Valahi, S. (2010). Voluntary IAS 1 accounting disclosures prior to official IAS adoption: An empirical investigation of UK firms. Research in International Business and Finance, 24(1), 1-14.

Jensen, M. C., \& Meckling, W. H. (1976). Theory of the firm: Managerial behavior, agency costs and ownership structure. Journal of Financial Economics, 3(4), $305-360$. doi:10.1016/0304405x(76)90026-x

Leuz, C., \& Verrecchia, R. E. (2000). The Economic Consequences of Increased Disclosure. Journal of Accounting $\mathrm{R}$ e s e a r c h, $38,91-124$. doi:10.2307/2672910

Marston, C. L., \& Shrives, P. J. (1991). The use of disclosure indices in accounting 
research: A review article. The British Accounting Review, 23(3), 195-210. doi:10.1016/0890-8389(91)90080-1

Meek, G. K., Roberts, C. B., \& Gray, S. J. (1995). Factors Influencing Voluntary Annual Report Disclosures By U.S., U.K. and Continental European Multinational Corporations. Journal of International Business Studies, 26(3), $\begin{array}{llllllll}5 & 5 & 5 & - & 5 & 7 & 2\end{array}$. doi:10.1057/palgrave.jibs. 8490186

Morris, R. D. (1987). Signalling, Agency Theory and Accounting Policy Choice. Accounting and Business Research, 18 ( 69 ), $\quad 47-56$. doi:10.1080/00014788.1987.9729347

Murcia, F. D., \& Santos, A. (2012). Discretionary- based disclosure: Evidence from the Brazilian market. Brazilian Administration Review, 9(1),
88-109.

Ross, S. A. (1977). The Determination of Financial Structure: The IncentiveSignalling Approach. The Bell Journal of E c on om ics, 8 ( 1 ), $23-40$. doi:10.2307/3003485

Singhvi, S. S., \& Desai, H. B. (1971). An empirical analysis of the quality of corporate financial disclosure. The Accounting Review, 46, 129-138.

United Nations Conference on Trade and Development. (2017). International Accounting and Reporting Issues. Retrieve from https://unctad.org/en/PublicationsLibrar y/diae d2017d8 en.pdf

Verrecchia, R. E. (1983). Discretionary disclosure. Journal of Accounting and Economics, 5(3), 179-194.

\section{VOLUNTARY DISCLOSURE CHECKLIST}

\begin{tabular}{|l|l|}
\hline $\mathbf{1}$ & STRATEGIC DETAILS \\
\hline & General Corporate Details \\
\hline 1 & Brief history of company \\
\hline 2 & Description of the organizational structure \\
\hline 3 & Description of principal services \\
\hline 4 & Description of the major subsidiaries and properties \\
\hline 5 & Description of marketing network for services \\
\hline 6 & Client analysis \\
\hline 7 & Number of customers \\
\hline 8 & Transitions through digital channels \\
\hline 9 & Accounts openings by digital means \\
\hline 10 & Transactions using debit cards \\
\hline 11 & Information on brand value \\
\hline 12 & Awards and recognition \\
\hline 13 & Description of commercial banking activity \\
\hline
\end{tabular}




\begin{tabular}{|c|c|}
\hline 14 & Description of retail banking activity \\
\hline 15 & Description of corporate banking activity \\
\hline 16 & Description of public sector banking activity \\
\hline 17 & Description of investment banking activity \\
\hline 18 & Information on best business practice \\
\hline 19 & Remuneration structure of directors \\
\hline 20 & Download volume of mobile applications \\
\hline 21 & Countries of presence and operation \\
\hline 22 & Digital evolution \\
\hline 23 & Notice of meeting \\
\hline 24 & Information on branches \\
\hline \multirow[t]{2}{*}{25} & Information on advisors and auditors \\
\hline & Corporate Strategy \\
\hline 26 & Statement of strategy, Policy and objectives - general \\
\hline 27 & Statement of strategy, Policy and objectives - financial \\
\hline 28 & Statement of strategic business operation \\
\hline 29 & Strategic development on current results \\
\hline 30 & Strategic development on future results \\
\hline 31 & Impact of technology on current banking activity \\
\hline 32 & Technological factors influencing future activity \\
\hline 33 & Discussion on past industry tendencies \\
\hline 34 & Discussion on future industry tendencies \\
\hline 35 & Description of activities with government entities \\
\hline 36 & Description of security operation on banking activity \\
\hline 37 & Development of new products / services \\
\hline 38 & Sustainable report \\
\hline 39 & Information on risk management \\
\hline 40 & Client satisfaction survey \\
\hline 41 & Client satisfaction survey results \\
\hline 42 & Client complaint management \\
\hline
\end{tabular}




\begin{tabular}{|l|l|}
\hline & Research and Development \\
\hline 43 & Corporate policy on research and development \\
\hline 44 & Location of research and development activities \\
\hline 45 & Number employed in research and development \\
\hline & Future Prospects \\
\hline 46 & Qualitative forecast of sales \\
\hline 47 & Quantitative forecast of sales \\
\hline 48 & Qualitative forecast of profits \\
\hline 49 & Quantitative forecast of profits \\
\hline 50 & Qualitative forecast of cash flows \\
\hline 51 & Quantitative forecast of cash flows \\
\hline 52 & Current period trading results - qualitative \\
\hline 53 & Current period trading results - quantitative \\
\hline $\mathbf{2}$ & NONFINANCIAL DETAILS \\
\hline & Details on Directors \\
\hline 54 & Age of the directors \\
\hline 55 & Educational qualifications (academic and professional) \\
\hline 56 & Commercial experience of the executive directors \\
\hline 57 & Other directorships held by executive directors \\
\hline 58 & Affiliation of directors with other organizations \\
\hline 59 & Information on Board meeting \\
\hline 60 & Functions/ responsibility and authority of board \\
\hline & Details on Employees \\
\hline 61 & Information on management team \\
\hline 62 & Number of employees \\
\hline 63 & Categories of employees by gender \\
\hline 64 & Human Resources: training and development of employees \\
\hline 65 & Amount spent on training \\
\hline 66 & Nature of training \\
\hline 67 & Number of employees trained \\
\hline 68 & Information on female empowerment \\
\hline 69 & Information on Internship programme \\
\hline & \\
\hline &
\end{tabular}




\begin{tabular}{|c|c|}
\hline 70 & Responsible business practice \\
\hline 71 & Equal opportunity policy statement \\
\hline 72 & Categories of employees trained \\
\hline \multirow[t]{2}{*}{73} & Special report on employees and social activities \\
\hline & Social Policy Details \\
\hline 74 & Environmental protection programs (Health, safety, well-being) \\
\hline 75 & Charitable donations (amount) \\
\hline 76 & Community programs (general) \\
\hline 77 & Political and social factors influencing future activity \\
\hline 78 & Relationships in social networks \\
\hline 79 & Financial education and inclusion \\
\hline \multirow[t]{2}{*}{3} & FINANCIAL DETAILS \\
\hline & Segment Details \\
\hline 80 & Capital expenditures, Investments - quantitative \\
\hline 81 & Competitor analysis - qualitative \\
\hline 82 & Competitor analysis - quantitative \\
\hline 83 & Market share analysis - qualitative \\
\hline 84 & Market share analysis - quantitative \\
\hline 85 & Information on depreciation \\
\hline 86 & Advertising information (information) - qualitative \\
\hline 87 & Advertising expenditure (amount) - quantitative \\
\hline 88 & Effects of inflation on future operations - qualitative \\
\hline 89 & Effects of inflation on results - qualitative \\
\hline 90 & Effects of inflation on results - quantitative \\
\hline 91 & Effects of inflation on assets - qualitative \\
\hline 92 & Effects of inflation on assets - quantitative \\
\hline 93 & Effects of interest rates on results \\
\hline 94 & Effects of interest rates on future operations \\
\hline 95 & Economic factors influencing future activity \\
\hline \multirow[t]{2}{*}{96} & Treasury bill rate \\
\hline & Financial Review \\
\hline 97 & Cash flow ratios \\
\hline
\end{tabular}




\begin{tabular}{|l|l|}
\hline 98 & Liquidity ratios \\
\hline 99 & Return on assets \\
\hline 100 & Return on equity \\
\hline 101 & Capital adequacy ratio \\
\hline 102 & Other financial ratios \\
\hline 103 & Financial highlights \\
\hline 104 & Dividend payout policy \\
\hline 105 & Financial history or summary - five or more years \\
\hline 106 & Information on fixed assets variations \\
\hline 107 & Value added statement \\
\hline 108 & Value added data \\
\hline 109 & Value added ratios \\
\hline 110 & Qualitative value added information \\
\hline & \\
\hline & Foreign Currency Information \\
\hline 111 & Effects of foreign currency fluctuations on results - qualitative \\
\hline 112 & Major exchange rates used in the accounts \\
\hline 113 & Foreign currency exposure management description \\
\hline & Stock Price Details \\
\hline 114 & Market capitalization and financial operations \\
\hline 115 & Trend of Historical share price \\
\hline 116 & Size of shareholdings \\
\hline 117 & Type of shareholder (Structure of ownership) \\
\hline 118 & Shareholders names \\
\hline & \\
\hline
\end{tabular}

\section{LIST OF ABBREVIATIONS}

AIMR - Association for Investment Management and Research

AMEX - American Express Company

ANOVA-Analysis of variance

BOG - Bank of Ghana

CPA-Certified Public Accountant Firm

CSD - Corporate Strategy Details

DoD - Details on Directors

DoE - Details on Employees
FCD - Foreign Currency Details

FD - Financial Details

FPD - Future Prospects Details

FRD - Financial Review Details

GCD - General Corporate Details

GSE - Ghana Stock Exchange

MNCs - Multinational Corporation

NFD - Nonfinancial Details

NYSE - New York Stock Exchange

OTC-Over-The-Counter 
R\&D - Research and Development

R\&D - Research and Development Details

SeD - Segment Details

SPoD - Social Policy Details

SPrD - Stock Price Details
StD - Strategic Details

TD - Total Disclosure

UNCTAD - United Nations Conference on

Trade and Development

VDI - Voluntary Disclosure Index 